\title{
TRANSMISSION OF THE ANESTHETIC AGENTS THROUGH THE PLACENTA IN PAINLESS DELIVERY AND THEIR EFFECTS OF NEWBORN INFANTS
}

\author{
KIYOO BEPPU \\ Department of Obstetrics and Gynecology, School of Medicine, \\ Keio University, Tokyo
}

(Received for publication March 26, 1968)

\begin{abstract}
Because the influence of anesthesia on newborn infants is vital, the transmission of the anesthetic agents through the placenta and their effects were studied in this respect. There are many reports about the transmission of an anesthetic agent through the placenta, but only a few reports which compare the transmission of several anesthetic agents have been reported. For this reason transmission of an intravenous anesthetic agent (thiopental) and several inhalation anesthetic agents (Halothane, Methoxyflurane, trichlorethylene and nitrous oxide) were compared and discussed systemically, basically and clinically in this research.

This research was done at the Keiyu Hospital in Yokohama from May 1962 to November 1967.
\end{abstract}

\section{TRANSMISSION OF THE ANESTHETIC AGENTS THROUGH THE PLACENTA}

A. Anesthesia by Intravenous Injection of Thiopental

In 1944, Hellman et al. ${ }^{1}$ reported 7 cases of transmission of barbiturates through the human placenta, using a spectrophotometer. Thirteen cases of transmission of thiopental through the placenta were analyzed by gas chromatography.

1. Method of extraction

a. Preparation: The method by K.D. Parker and P.L. Kirk ${ }^{2}$ was modified. Ten milliliter of blood were put into a funnel. Thirty milliliter of chloroform were added three times and well shaken. The chloroform layer was extracted by 
$10 \mathrm{ml}$ of $1 / 2 \mathrm{~N} \mathrm{NaOH}$. This extracted solution was added to $\mathrm{HCl}$ and become $\mathrm{pH}_{4}$. Fifteen milliliter of chloroform was added and then it was well shaken and centrifuged. Then the chloroform layer was extracted and was filtered. It was desiccated at $50^{\circ} \mathrm{C}$ and the remnant was resolved into $1 \mathrm{ml}$ of acetone. The volume of resolved solution used as the sample was $0.02 \mathrm{ml}$.

b. Type and condition of gas chromatography:

Type: Parkin Elmer 154-C

Condition: Column: Silicone DC, QF-1 5\% (1/4 inch $\times 1 \mathrm{~m})$

Column temperature: $150^{\circ} \mathrm{C}$

Carrier gas: He $26 \mathrm{ml} / \mathrm{min}$

Detector: $\mathrm{H}_{2}$ flame ionization detector

c. Quantitative analysis: Triangular method was used for the quantitative analysis.

\section{Result (Table 1)}

The result of 13 cases, including 8 cesarean sections, was as follows:

a. Correlation between the highest concentration of thiopental in mothers and infants and the lapse of time: The highest concentration of thiopental in the cubital veins of the mothers was 14 minutes from the injection and in the

Table 1

Transmission of Thiopental through Placenta

\begin{tabular}{|c|c|c|c|c|c|c|c|c|}
\hline No. & Time & $\begin{array}{l}\text { Mother } \\
\gamma / 100 \mathrm{ml}\end{array}$ & $\begin{array}{l}\text { Infant } \\
r / 100 \mathrm{ml}\end{array}$ & Apgar & $\begin{array}{c}\text { Ist } \\
\text { Resp. }\end{array}$ & $\begin{array}{l}\text { lst } \\
\text { Cry. }\end{array}$ & Sleepy & $\begin{array}{c}\text { Mode of } \\
\text { Birth }\end{array}$ \\
\hline $\begin{array}{r}1 \\
2 \\
3 \\
4 \\
5 \\
6 \\
7 \\
8 \\
9 \\
10 \\
11\end{array}$ & $\begin{array}{l}1^{\prime} 49^{\prime \prime} \\
325 \\
449 \\
500 \\
534 \\
826 \\
1114 \\
1236 \\
1355 \\
1616 \\
2140\end{array}$ & $\begin{array}{r}747 \\
8 \overline{7} \\
867 \\
647 \\
500 \\
270 \\
1987 \\
1011 \\
670 \\
920\end{array}$ & $\begin{array}{r}311 \\
\overline{689} \\
861 \\
723 \\
595 \\
653 \\
1030 \\
256 \\
684 \\
527\end{array}$ & $\begin{array}{l}9 \\
7 \\
8 \\
9 \\
8 \\
9 \\
8 \\
8 \\
7 \\
6 \\
8\end{array}$ & $\begin{array}{l}0 / \mathrm{min} \\
0 \\
0 \\
0 \\
0 \\
0 \\
0 \\
0 \\
0 \\
3 \\
0\end{array}$ & $\begin{array}{c}2 / \min \\
10 \\
5 \\
0 \\
0 \\
2 \\
0 \\
10 \\
10 \\
120 \\
5\end{array}$ & $\begin{array}{l}- \\
\pm \\
\pm \\
= \\
\overline{+} \\
+ \\
+ \\
+ \\
\pm\end{array}$ & $\begin{array}{l}\text { Vag del. } \\
\text { C-sec. } \\
\text { Vag del. } \\
\text { C-sec. } \\
\text { C-sec. } \\
\text { C-sec. } \\
\text { C-sec. } \\
\text { C-sec. } \\
\text { C-sec. } \\
\text { C-sec. } \\
\text { C-sec. }\end{array}$ \\
\hline
\end{tabular}

umbilical vein was 5 minutes from the injection. This time was somewhat later than that of other reports. ${ }^{3-5}$

b. Rate of transmission of thiopental through placenta: When the concentration of thiopental in the mothers was stipulated as standard (100) and transmission of thiopental to the infants was checked with the time from the 
injection, the concentration of mothers and infants became equal at 6 minutes from the injection. Then the concentration of the infants became the highest at 11 minutes from the injection and then the rate of transmission decreased gradually. If the concentration of the mothers was higher, the transmission to the infants was greater.

c. Correlation with asphyxia of newborn infants: Apgar score was 6-9 (mean 8.0). There were 7 sleepy babies in 13 deliveries. No asphyxia of the babies was present and there was no correlation between the concentration and asphyxia of newborn infants.

\section{Summary}

Hellman ${ }^{1}$ reported that the transmission of sodium pentothal through the placenta at 5 minutes from the injection and the concentration of blood of mothers and infants became equal at 10-12 minutes after the injection. The other authors ${ }^{3-5}$ reported that the transmission to the infants appeared within 2 minutes and that the concentration of mothers and infants became equal within 3 minutes. Other authors ${ }^{6,7}$ have reported that the transmission to the infants appeared within 45 seconds and the concentration of the mothers and infants became equal at 3 minutes after the injection. Crowford ${ }^{4}$ reported in 1955 that the highest concentration appeared in the infants, of whom the interval between the injection and delivery was the shortest. In this research, transmission to the infant appeared at $1^{\prime} 49^{\prime \prime}$ from the injection. The concentration of the infants became higher than the mothers at 3, 5, 8 and 11 minutes after the injection. This result was different from the other reports quoted above. The reason is probably due to the very close concentration of the mothers and infants. The depression of the infants depends probably on the dosage of the barbiturate and not on the lapse of time from the injection. Five hundred milligram of thiopental was safe enough for the infants.

\section{B. Anesthesia by Methoxyflurane (M.T.F.) Inhalation}

\section{Method of experiment}

Three hundred milligram of pentobarbital sodium was given orally and $50 \mathrm{mg}$ of meperidine was intramuscularly injected in the mother during the first stage of the delivery. When the cervix of the uterus was fully dilated, a few ml of M.T.F. were inhaled by the mother through a Walton $V$ vaporizer. At the same time, $100 \mathrm{mg}$ of pentobarbital was intravenously injected. The concentration of M.T.F. was kept between 0.5 and 1.5 vol \%. As soon as the baby 
was delivered, the blood circulation of the umbilical cord was interrupted by a Kocher forceps, and then $10 \mathrm{ml}$ of blood was withdrawn from the umbilical vein. At the same time, $10 \mathrm{ml}$ of blood was withdrawn from the cubital vein of the mother. A syringe of Luer-Lock type was used for withdrawal of blood and the inside of the syringe was coated with heparin as an anticoagulant. The entrance of the air was shut out by paraffin. The syringe was closed tightly with a specially made metal cap.

2. Quantitative analysis by gas chromatography

a. Extraction of M.T.F.: Ten milliliter of blood was put into a centrifuge tube and a small amount of mercury was added. In addition, $3 \mathrm{ml}$ of distilled toluene was added and the biood was well shaken for 5 minutes and then centrifuged at $3000 \mathrm{rpm}$ for 5 minutes. The sample in the centrifuge tube was cooled in a refrigerator and $0.1 \mathrm{ml}$ of the upper layer of the sample was taken for gas chromatography. The extraction rate of M.T.F. was $97.3 \%$.

b. Type and condition of gas chromatograph:

Type: Parkin Elmer 154-C, Thermal conductivity cell

Column: Diisodecyl phthalate, 1/1 inch, 2 meters

Carrier gas: $30 \mathrm{ml} / \mathrm{min} \mathrm{He}$ (10 psi)

Cell volt: 10 volt D.C.

Chart speed: $1 / 2 \mathrm{inch} / \mathrm{min}$

Sample volume: $0.10 \mathrm{ml}$

3. Result (Table 2)

Inhalation time of M.TF. of 20 cases was from 4 to 60 minutes, the mean

Table 2

Comparison of the Concentration of Various Anesthetic Agents in Blood of Mothers and Infants

(Vaginal delivery)

\begin{tabular}{|c|c|c|c|c|c|c|c|}
\hline \multirow{2}{*}{ Vaporizer } & \multirow{2}{*}{$\begin{array}{l}\text { No. of } \\
\text { Cases }\end{array}$} & \multirow{2}{*}{$\underset{\underset{(\min )}{\text { Inhala- }}}{\text { tion Time }}$} & \multirow{2}{*}{$\begin{array}{c}\text { Inhala- } \\
\text { tion Vol. } \\
(\mathrm{ml})\end{array}$} & \multicolumn{2}{|c|}{ Mother $(\mathrm{mg} / \mathrm{dl})$} & \multicolumn{2}{|c|}{ Infant $(\mathrm{mg} / \mathrm{d} \mathrm{l})$} \\
\hline & & & & $\begin{array}{c}\text { Cubital } \\
\text { Vein }\end{array}$ & $\begin{array}{l}\text { Cubital } \\
\text { Artery }\end{array}$ & $\underset{\text { Vein }}{\text { Umbilical }}$ & Umbilical \\
\hline $\begin{array}{l}\text { Nitrous oxide } \\
\text { (Walton-V) }\end{array}$ & 20 & 24 & $50-80 \%$ & $\begin{array}{r}16.85 \\
\pm 10.60\end{array}$ & $\begin{array}{r}23.82 \\
\pm 14.55\end{array}$ & $\begin{array}{r}11.02 \\
\pm 7.25\end{array}$ & $\begin{array}{r}7.51 \\
\pm 3.67\end{array}$ \\
\hline $\begin{array}{l}\text { Trichlorethylene } \\
\text { (Goldman) }\end{array}$ & 34 & 35 & 4.3 & $\begin{array}{r}2.36 \\
\pm 1.17\end{array}$ & $\begin{array}{r}2.80 \\
\pm 1.14\end{array}$ & $\begin{array}{r}1.83 \\
\pm 1.08\end{array}$ & $\begin{array}{r}1.91 \\
\pm 0.95\end{array}$ \\
\hline $\begin{array}{l}\text { Halothane } \\
\text { (Fluotec) }\end{array}$ & 42 & 32 & 8.4 & $\begin{array}{r}6.07 \\
\pm 3.46\end{array}$ & $\begin{array}{r}4.53 \\
\pm 3.03\end{array}$ & $\begin{array}{r}2.50 \\
\pm 1.77\end{array}$ & $\begin{array}{r}2.19 \\
\pm 1.26\end{array}$ \\
\hline $\begin{array}{l}\text { M.T.F. } \\
\text { (Pentec) }\end{array}$ & 20 & 24 & 7.1 & $\begin{array}{r}5.31 \\
\pm 2.19\end{array}$ & & $\begin{array}{r}1.32 \\
\pm 0.50\end{array}$ & \\
\hline
\end{tabular}


being 24 minutes. The volume of inhalation was from 2 to $10 \mathrm{ml}$, the mean being $7.2 \mathrm{ml}$. The average concentration of M.T.F. in the cubital vein of mother was $5.31 \pm 2.19 \mathrm{mg} / \mathrm{dl}$ and the average concentration in the umbilical vein was $1.32 \pm 0.50 \mathrm{mg} / \mathrm{dl}$. There was a significant correlation between these concentrations $\left(t_{s}=4.296, t_{s}<t=1 \%\right)$; therefore, the maternal-fetal gradient of the contration was the mother's vein $\rightarrow$ umbilical vein and the concentration of the infant was lower than the concentration of the mother. There was no asphyxia in any infant in these 20 cases with only one sleepy case. Apgar score was from 6 to 10 and the mean was 8.5 .

C. Anesthesia by Halothane Inhalation

As far as the concentration of Halothane was concerned, only Sheridan ${ }^{8}$ reported in 1959, 6 cases of estimation of blood from the cubital veins and the umbilical cords. In this research, blood from the cubital artery, cubital vein, intravillous space and umbilical vein and artery of 41 vaginal deliveries and 9 cesarean sections was analyzed by gas chromatography.

1. Type and condition of gas chromatography

Type: Shimazu GC-IC

Condition: Column: Diisodecyl phthalate $20 \%(3 \mathrm{~mm} \times 26 \mathrm{~m})$

Column temperature: $80^{\circ} \mathrm{C}$

Detector temperature: $105^{\circ} \mathrm{C}$

Sample chamber temperature: $100^{\circ} \mathrm{C}$

Carrier gas: $\mathrm{N}_{2} 20 \mathrm{ml} / \mathrm{min}$

Detector: Flame ionization detector

\section{Extraction of Halothane}

Five milliliter of blood in a centrifuge tube was added with $15 \mathrm{ml}$ of $\mathrm{N}$ heptane and was well shaken and was centrifuged $2000 \mathrm{rpm}$ for 3 minutes. It was cooled and the blood was coagulated. Then $10 \mathrm{ml}$ of the sample from the $\mathrm{N}$ heptane was put into gas chromatography. The extraction rate of Halothane was $85 \%$.

3. Result

a. Vaginal delivery (Table 2): The inhalation time of Halothane of 41 cases was from 6 to 115 minutes; the mean was 32 minutes. The inhalation volume was from 2 to $20 \mathrm{ml}$; the mean was $8.4 \mathrm{ml}$. The average concentration of halothane in the mothers' and infant's blood was $4.35 \pm 3.03 \mathrm{mg} / \mathrm{dl}$ in the 
cubital vein, $2.50 \pm 1.77 \mathrm{mg} / \mathrm{dl}$ in the umbilical vein and $1.64 \pm 0.99 \mathrm{mg} / \mathrm{dl}$ in the umbilical artery; that is, the concentration of the infant's blood was lower than that of the mother's blood. There was significant correlation between the blood of the mother's artery and vein but there was a significant correlation between the blood of the mother's artery and umbilical vein. ( $t_{s}=2.482, t=$ $5 \%<t_{s}<1 \%$ ). Moreover, there was no correlation between the blood of the umbilical artery and vein. Therefore, the gradient of concentration was from the mother's artery $\rightarrow$ umbilical vein. There were 2 cases of asphyxia and 4 sleepy babies in 41 deliveries and Apgar score was from 6 to 9 ; the mean 8.5.

b. Relation between the concentration of Halothane and inhalation time: There were 39 cases in which inhalation time was within one hour and 3 cases in which inhalation time was over one hour. In the former group, the concentration of mother's artery was $4.33 \mathrm{mg} / \mathrm{dl}$ and in the latter group, it was $6.33 \mathrm{mg} / \mathrm{dl}$. Similariy, the concentration of the arterial blood of the infant was $2.33 \mathrm{mg} / \mathrm{dl}$ in the former group and $3.73 \mathrm{mg} / \mathrm{dl}$ in the latter group. However, there was no correlation between the inhalation time and the inhalation volume statistically. The reason for this observation was probably due to intermittent anesthesia.

c. Relationship between the concentration of blood and depression of the infants: There were 2 cases of asphyxia and 5 sleepy babies of the former 39 cases and there was no depressed baby in the latter 3 cases. Therefore, there was probably no correlation between the two factors. Moreover, the concentratration of the maternal arterial blood of the asphyxia group was $2.16 \mathrm{mg} / \mathrm{dl}$ and that of the infants' arterial blood was $1.94 \mathrm{mg} / \mathrm{dl}$. On the other hand, the concentration of the maternal arterial blood of the normal group was 5.10 $\mathrm{mg} / \mathrm{dl}$ and that of the infants' arterial blood was $2.50 \mathrm{mg} / \mathrm{dl}$. Therefore, the

\section{Table 3}

Comparison of the Concentration of Halothane and Nitraus Oxide in the Blood of Mothers and Infants

(Cesarean section)

\begin{tabular}{|c|c|c|c|c|c|c|c|}
\hline \multirow[b]{2}{*}{ Vaporizer } & \multirow{2}{*}{$\begin{array}{l}\text { No. of } \\
\text { Cases }\end{array}$} & \multirow{2}{*}{$\begin{array}{l}\text { Inhala- } \\
\text { tion Time } \\
\quad(\mathrm{min})\end{array}$} & \multicolumn{2}{|c|}{ Mother (mg/dl) } & \multicolumn{3}{|c|}{ Infant $(\mathrm{mg} / \mathrm{dl})$} \\
\hline & & & $\begin{array}{l}\text { Cubital } \\
\text { Artery }\end{array}$ & $\begin{array}{l}\text { Cubital } \\
\text { Vein }\end{array}$ & $\begin{array}{l}\text { Intravil- } \\
\text { lous } \\
\text { Space }\end{array}$ & $\underset{\text { Vein }}{\text { Umbilical }}$ & $\begin{array}{l}\text { Umbilical } \\
\text { Artery }\end{array}$ \\
\hline $\begin{array}{l}\text { Halothane } \\
\text { (Boyle-K) }\end{array}$ & 9 & 24 & $\begin{array}{r}9.69 \\
+3.31\end{array}$ & $\begin{array}{r}5.16 \\
\pm 1.81\end{array}$ & $\begin{array}{r}7.26 \\
\pm 2.68\end{array}$ & $\begin{array}{r}6.29 \\
\pm 2.28\end{array}$ & $\begin{array}{r}5.85 \\
\pm 1.12\end{array}$ \\
\hline $\begin{array}{l}\text { Nitrous Oxide } \\
\text { (Boyle-K) }\end{array}$ & 6 & 24 & $\begin{array}{r}26.25 \\
\pm 13.40\end{array}$ & $\begin{array}{r}25.76 \\
\pm 10.70\end{array}$ & $\begin{array}{r}24.50 \\
\pm 8.90\end{array}$ & $\begin{array}{r}18.50 \\
\pm 6.00\end{array}$ & $\begin{array}{r}18.43 \\
\pm 3.46\end{array}$ \\
\hline
\end{tabular}


cause of depression of the infants was not due to high concentration of Halothane in the blood. The higher concentration of maternal venous blood over that of maternal arterial blood is possibly due to retrograde flow of blood from the infants, since there is a significant correlation between the maternal and infants' venous blood. $(r=0.8992, p<0.01, Y=0.38 \times+0.17)$.

d. Cesarean section (Table 3 ) : Half milligram of atropine sulfate and 70 $\mathrm{mg}$ of meperidine were administered for premedication of anesthesia. Nitrous oxide was used for induction of anesthesia. The inhalation time was 15 to 32 minutes: the mean 24 minutes. The inhalation volume was approximately $10 \mathrm{ml}$. The concentration of the mothers' and infants' blood was $9.69 \pm 3.31 \mathrm{mg} / \mathrm{dl}$ in the cubital artery, $7.26 \pm 2.68 \mathrm{mg} / \mathrm{dl}$ in the intravillous space and $6.29 \pm 2.28$ $\mathrm{mg} / \mathrm{dl}$ in the umbilical arterv. There was a significant correlation between the arterial blond of mothers and infants $\left(t_{s}=2.564, t=5 \%>t_{s}>1 \%\right)$ and there was no significant correlation between the arterial and venous blood of infants. There was also no significant correlation between the venous blood of mothers and infants. Therefore, the gradient of concentration was the blood of the cubital artery $\rightarrow$ umbilical vein; that is, the concentration of maternal blood was higher than that of the infants' blood. As far as the depression of these 9 infants was concerned, there was no case of asphyxia or sleepy baby. The Apgar score was 8 to 9 ; the mean 8.6.

\section{Summary}

The concentration of the maternal arterial blood was $4.53 \mathrm{mg} / \mathrm{dl}$ upon vaginal delivery and $9.69 \mathrm{mg} / \mathrm{dl}$ upon cesarean section; that is, the concentration upon cesarean section was about twice of that upon vaginal delivery. The concentration of the umbilical vein was $2.50 \mathrm{mg} / \mathrm{dl}$ upon vaginal delivery and was 6.29 $\mathrm{mg} / \mathrm{dl}$ upon cesarean section; that is, the concentration upon cesarean section was over twice that of vaginal delivery. However, there was no difference in the depressions of infants upon vaginal delivery and cesarean section. This means that the mechanism of the first respiration of infants was not disturbed in the range of concentration 2 to $6 \mathrm{mg} / \mathrm{dl}$.

\section{Anesthesia by Trichlorethylene Inhalation}

As far as the concentration of trichlorethylene in human blood is concerned, Fujio et al..$^{9}$ reported the method in 1955 in Brain method. ${ }^{10}$ Thirty-four vaginal deliveries were analysed, of which inhalation anesthesia was through a Goldman vaporizer. Blood was withdrawn from the femoral (cubital) arteries, cubital veins of mothers and umbilical veins and arteries. The analysis was 
done by gas chromatography.

1. Type and condition of gas chromatography

Type: Shimazu GC-IC

Condition: Column: Diisodecyl phthalate $20 \%(3 \mathrm{~mm} \times 2.6 \mathrm{~m})$

Column temperature: $90^{\circ} \mathrm{C}$

Detector temperature: $100^{\circ} \mathrm{C}$

Carrier gas: $\mathrm{N}_{2} 30 \mathrm{ml} / \mathrm{min}$

Detector: $\mathrm{H}_{2}$ flame ionization detector

2. Method of extraction of trichlorethylene

Three milliliter of blood was put into a centrifuge tube and $1 \mathrm{ml}$ of o-xylene was added and was well shaken. It was then centrifuged for 3 minutes at 2000 rpm. It was then refrigerated and the blood was coagulater. Five $\mathrm{ml}$ of the sample from the o-xylene layer was injected into the gas chromatograph. The withdrawal rate was $88.7 \%$.

\section{Result (Table 2)}

Inhalation time of trichlorethylene of 34 vaginal deliveries varied from 2 to 98 minutes: the mean was 34.7 minutes. The volume of inhalation was from 2 to $8 \mathrm{ml}$; the mes $n$ being $4.3 \mathrm{ml}$. The mean concentration of trichlorethylene was $2.80 \pm 1.14 \mathrm{mg} / \mathrm{dl}$ in the femoral (cubital) arteries of mother. $2.36 \pm 1.17$ $\mathrm{mg} / \mathrm{dl}$ in the cubital veins of mothers, and $1.83 \pm 1.08 \mathrm{mg} / \mathrm{dl}$ in the umbilical veins and $1.91 \pm 0.95 \mathrm{mg} / \mathrm{dl}$ in the umbilical arteries. The concentration of the latter group was lower than that of the former group. There was no significant correlation between the maternal arterial and venous blood, but there was a significant correlation between the maternal arterial blood and infants' venous blood. $\left(t_{s}=2.485, t=1 \%>t_{s}>t=5 \%\right)$. There was no significant correlation between the arterial and venous blood of infants. Therefore, the gradient of concentration was from mother's arterial blood $\rightarrow$ fetal arterial blood; that is, the concentration of the fetal blood was lower than that of the mothers' blood. As far as the depression of these 34 babies was concerned. there was one case of asphyxia and three sleepy babies with Apgar scores of 5 to 9 , the mean being 8.5 .

Comparison was made between 29 cases in which inhalation time was within one hour and 5 cases in which inhalation time was over one hour. In the former group, the concentration of maternal arteries was $2.89 \mathrm{mg} / \mathrm{dl}$ and that of the fetal arteries was $1.72 \mathrm{mg} / \mathrm{dl}$. In the latter group, the concentration of the maternal arteries was $2.42 \mathrm{mg} / \mathrm{dl}$ and of the fetal arteries was $2.50 \mathrm{mg} / \mathrm{dl}$. 
The concentration of maternal arteries of latter group was lower than that of the former group. With respect to fetal distress, however, there were a single case of asphyxia and 3 cases of sleepy baby in the former group with no depression being present in the latter group. Therefore, there was no correlation between the inhalation time and fetal distress. The concentration of the maternal arterial blood in the fetal distress group was $2.70 \mathrm{mg} / \mathrm{dl}$ and that of the fetal arterial blood was $1.86 \mathrm{mg} / \mathrm{dl}$. The concentration of the maternal arterial blood in the normal fetal group was $2.72 \mathrm{mg} / \mathrm{dl}$ and that of the fetal arterial blood was $1.86 \mathrm{mg} / \mathrm{dl}$. There was no significant correlation between these two groups.

\section{Summary}

When trichlorethylene was used through a Cyplane vaporizer for anesthesia of delivery, the inhalation time should be within one hour because when the inhalation time was over one hour, the concentration of maternal and fetal blood approximately doubles and fetal distress might develop. On the other hand, when trichlorethylene was administered through a Goldman vaporizer, there was no correlation between the inhalation time and fetal distress, except for the increase in concentration in fetal blood. The above reason is probably due to the use of oxygen.

E. Anesthesia by Nitrous Oxide Inhalation

In 1939. Smith ${ }^{11}$ reported the concentration of nitrous oxide in blood upon cesarean section. In 1953 , Cohen et al..$^{12}$ also reported the $\mathrm{N}_{2} \mathrm{O}$ concentration in cesarean section, using at the same time thiopental and curare. Both reports showed that the concentration of the umbilical blood was lower than that of the maternal blood. In our study, the results were based on 20 vaginal deliveries and 6 cesarean sections, using 50-80\% nitrous oxide. The blood was withdrawn from the femoral or cubital arteries and cubital veins of mothers and the umbilical veins and arteries. Gas chromatography was used for analysis and the procedures were as follows:

1. Type and condition of gas chromatography

Type: Shimazu GC-IC

Condition: Column: Silicagel $(3 \mathrm{~mm} \times 2.25 \mathrm{~m})$

Column temperature: $30^{\circ} \mathrm{C}$

Detector temperature: $100^{\circ} \mathrm{C}$

Carrier gas: $\mathrm{He} 20 \mathrm{ml} / \mathrm{min}$

Detector: Thermal conductivity detector

2. Method of quantitative analysis 
One milliliter of blood was put into $10 \mathrm{ml}$ of vial and then it was well shaken. It was kept at $37^{\circ} \mathrm{C}$ for 2 hours. One milliliter of the vapor was put into the gas chromatograph. The concentration of nitrous oxide was calculated and compared with the calibration curve.

3. Result

a. Vaginal delivery (Table 2): The inhalaiton time of 20 vaginal deliveries ranged from 4 to 108 minutes; the mean being 28 minutes. The mean value of the concentration of maternal and fetal blood was $23.82 \pm 1455 \mathrm{mg} / \mathrm{dl}$ in the femoral (cubital) arteries of mothers, $16.85 \pm 10.60 \mathrm{mg} / \mathrm{dl}$ in the cubital veins of mothers, $11.02 \pm 7.25 \mathrm{mg} / \mathrm{dl}$ in the umbilical veins and $7.50 \pm 3.70 \mathrm{mg} / \mathrm{dl}$ in the umbilical arteries. There was a significant correlation between the maternal arterial and venous blood $\left(\mathrm{t}_{s}=2.451, \mathrm{t}=5 \%<\mathrm{t}_{s}<1 \%\right)$. There was a significant correlation between the maternal arterial and fetal arterial blood $(\mathrm{t}=\mathbf{2 . 6 8 2}$, $\left.\mathrm{t}=5 \%<\mathrm{t}_{s}<1 \%\right)$. There was a significant correlation between the maternal venous and the fetal venous blood $\left(t_{s}=2.653, t=5 \%<t_{s}<1 \%\right)$. There was also a significant correlation between the fetal arterial and venous blood $\left(t_{s}=2.463, t=5 \%<t_{s}<1 \%\right)$. Therefore, the gradient of concentration was the femoral artery $\rightarrow$ umbilical vein $\rightarrow$ umbilical artery, that is, the concentratoin of fetal blood was lower than the maternal blood As far as the depression of these infants was concerned, there was no case of asphyxia and only 2 sleepy babies. Apgar score was 6 to 9 ; the mean was 8.8 .

b. Cesarean section (Table 3) : Half milligram of atropine sulfate, $50 \mathrm{mg}$ of meperidine were used for premedication of anesthesia. Halothane was also used for the maintenance of anesthesia. The inhalation time of nitrous oxide was from 18 to 36 minutes; the mean was 24 minutes. The mean concentration of nitrous oxide in the maternal and fetal blood was $26 \pm 13.40 \mathrm{mg} / \mathrm{dl}$ in the cubital arteries of the mothers. $25.76 \pm 10.70 \mathrm{mg} / \mathrm{dl}$ in the cubital veins of the mothers, $24.50 \pm 8.90 \mathrm{mg} / \mathrm{dl}$ in the intravillous space, $18.50 \pm 6.00 \mathrm{mg} / \mathrm{dl}$ in the umbilical veins and $1843 \pm 3.46 \mathrm{mg} / \mathrm{dl}$ in the umbilical arteries. Therefore, the gradient of concentration was the maternal arteries $\rightarrow$ the umbilical veins $\rightarrow$ the umbilical arteries; that is, the concentration of the fetal blood was lower than that of the maternal blood. There were no cases of asphyxia or sleepy babies in these 6 infants and the Apgar score was 6-9, the mean being 8.8

\section{Summary}

$\mathrm{Smith}^{11}$ reported that the concentration of nitrous oxide in maternal arterial blood was 28.0 vol\%, the maternal venous blood was $21.7 \mathrm{vol} \%$, the umbilical 
venous blood was 9.8 vol\% and the umbilical arterial blood was 13.5 vol\% when ether was used at the same time. Cohen ${ }^{12}$ reported that the $\mathrm{N}_{2} 0$ concentration of the maternal venous blood was 13.6 vol\% and that of the fetal blood was 7.8 vol\% when thiopental and curare were used at the same time in cesarean sections; that is, the concentration in the fetal blood was lower than that in the maternal blood. The results of this study also the same tendency. There was no significant difference between the anesthetic vaginal delivery and cesarean section, as far as the concentration of nitrous oxide in blood was concerned. This reason was probably due to the fact that a large amount of nitrous oxide was not given since Halothane was also used at the same time in the cesarean sections.

F. Concentration of Anesthetic Agent in the Tissue of Mothers and Fetus (Rabbits, human being)

The anesthetic agents are absorbed by the organs through the blood stream and metabolized. There are only a few reports concerning these facts and these are limited to the barbiturates. ${ }^{13.14}$ In this research, trichlorethylene inhalation anesthesia was administered to near-term rabbits and their organs were examined to see how trichlorethylene was absorbed. The same experiment was carried out on a human fetus which was artificially induced at the 22 weeks gestation.

\section{Rabbits}

Trichlorethylene anesthesia was administered through a Goldman vaporizer on three pregnant rabbits (three days before E.D.C.) and on a non-pregnant rabbit. Their body weight ranges from 3026 to $3525 \mathrm{~g}$. Twenty liters per minute of oxygen was also administered at the same time. The concentration of trichlorethylene in the mask was approximately 0.45 vol\%. Ten minutes after starting the inhalation, the rabbit was killed by the injection of air into the veins of its ear. Two rabbits died spontaneously at 12.5 and 14.5 minutes after the beginning of inhalation, respectively. The organs were taken and homogenized in 20,000 rpm and then quantitative analysis was done by the G.L.C. method. The organs of the mothers which were analyzed were blood in the heart, brain tissue near the fourth ventricles, liver and kidneys. The organs in infants were placenta, brain tissue near the fourth ventricle, heart, liver and kidneys.

a. The organs of mother of rabbit (Table 4): The concentration of trichlorethylene in blood withdrawn ten minutes after the induction of anesthesia shows $2.4-3.0 \mathrm{mg} / \mathrm{dl}$. As far as the concentration of maternal organs was concerned (blood being 1.0 ), brain was 1.1 , heart 0.9 , liver 0.9 , and kidney 0.8 . These 
Table 4

Concentration of Trichlorethylene in Mothers and Fetus of Rabbits (G.L.C. method)

\begin{tabular}{|c|c|c|c|c|c|c|}
\hline Rabbit & $\begin{array}{l}\text { Art. Blood } \\
\mathrm{mg} / \mathrm{dl}\end{array}$ & $\underset{\mathrm{mg} / 100 \mathrm{~g}}{\text { Brain }}$ & $\begin{array}{c}\text { Liver } \\
\text { mg/100g }\end{array}$ & $\underset{\mathrm{mg} / 100 \mathrm{~g}}{\text { Heart }}$ & $\underset{\mathrm{mg} / 100 \mathrm{~g}}{\text { Kidney }}$ & $\begin{array}{l}\text { Placenta } \\
\mathrm{mg} / 100 \mathrm{~g}\end{array}$ \\
\hline 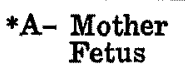 & 2.4 & 3.0 & 2.1 & 1.5 & 1.3 & \\
\hline *B- Mother & 1.4 & 4.8 & 2.8 & 3.0 & 3.5 & 1.0 \\
\hline 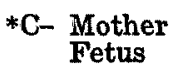 & 3.0 & $\begin{array}{l}2.7 \\
\text { trace }\end{array}$ & 2.7 & 3.5 & $\begin{array}{l}3.1 \\
\text { trace }\end{array}$ & 1.6 \\
\hline${ }^{* D}-\begin{array}{c}\text { Mother } \\
\text { Fetus }\end{array}$ & 3.4 & $\begin{array}{c}2.8 \\
\text { trace }\end{array}$ & $\begin{array}{c}3.5 \\
\text { trace }\end{array}$ & 2.9 & 3.8 & 2.3 \\
\hline
\end{tabular}

*A Non-pregnant rabbit

${ }^{*} \mathrm{~B}$ Expired at 12.5 minutes

${ }^{*} \mathrm{C} \quad$ Killed at 10 minutes

${ }^{*} \mathrm{D} \quad$ Expired at $\mathbf{1 4 . 5}$ minutes

figures are comparable to those reported by Matsumae, ${ }^{15}$ who stated that thiopental was rapidly absorbed in blood plasma, brain and adipose tissue.

b. The organs of fetus of rabbit: Ten minutes after the start of inhalation, the ratio of the concentration of trichlorethylene in the placenta to that in the blood was 0.5 and in the brain and kidneys there was only a trace of this anesthesia agent. On the contrary, J. Fealy reported that $2.5 \mathrm{mg} / \mathrm{ml}$ of Pentobarbital was found in the umbilical cord and $7.0 \mathrm{mg} / \mathrm{ml}$ of it was found in the liver in the case of macrocephalus. B.H. Person ${ }^{13}$ reported that the concentration of Barbiton (per os ) and Amylobarbitone (I.V.) in the blood of the mother and fetus was almost the same and twice that in the brain tissue of the fetus; that is, the inhalation anesthetic agent was probably not transmitted to the fetus, in contrast with the barbiturates.

c. Concentration in the blood and tissue of the expired rabbits: In two rabbits which died spontaneously at 12.5 and 14.5 minutes after the start of inhalation, $3.4 \mathrm{mg} / \mathrm{dl}$ of trichlorethylene was found in the maternal blood of the former and $1.4 \mathrm{mg} / \mathrm{dl}$ was found in blood of the latter. This meant that there was no realtionship between the concentration of the blood of mothers and the deaths themselves. However, a high concentration ratio was noted in the maternal organs of the former case (brain 3.4, heart 2.1, liver 2.0, kidneys 2.5), that is, the cause of death could have been the high concentration of the anesthetic agent in the organs.

d. Effect on the tissues of the fetuses in the dead rabbits: Two rabbits 
probably died of the high concentration in the organs, but only $70 \%$ of the concentration was noted in the placenta and was a trace in the brains and livers of the fetuses. In these cases, all 13 fetuses were alive at birth and 7 of them respirated at birth.

\section{Tissues of the human fetus (Table 5)}

On a mother of 22 weeks gestation, 0.70 vol\% of trichlorethylene inhalation was administered for 4 minutes through a Goldman vaporizer and then the fetus was artificially delivered. The concentration of the maternal arterial blood

Table 5

Concentration of Trichlorethylene in Human Mother and Fetus (G.L.C. method)

\begin{tabular}{c|c|c|c|c|c|c|c|c|c}
\hline \hline $\begin{array}{l}\text { No. of } \\
\text { Cases }\end{array}$ & $\begin{array}{c}\text { Inhala- } \\
\text { tion Time } \\
\text { (Minute) }\end{array}$ & $\begin{array}{c}\text { Inhala- } \\
\text { tion } \\
\text { Volume } \\
\text { (ml) }\end{array}$ & $\begin{array}{c}\text { Mother (mg/dl) } \\
\text { Cub. }\end{array}$ & $\begin{array}{c}\text { Cub. } \\
\text { Vein }\end{array}$ & $\begin{array}{l}\text { Pla- } \\
\text { centa }\end{array}$ & Brain & Heart & Liver & $\begin{array}{l}\text { Kind- } \\
\text { ney }\end{array}$ \\
\hline 1 & 4 & 3 & 3.0 & 3.3 & - & - & 0.9 & - & - \\
\hline
\end{tabular}

was $3.0 \mathrm{mg} / \mathrm{dl}$ and $0.9 \mathrm{mg} / \mathrm{dl}$ was found in the heart of fetus. No trichlorethylene was found in the placenta, brain, liver and kidneys.

\section{EFFECTS ON NEWBORN INFANTS}

A. Basic Experiments

1. Observation of the intra-uterine respiratory movements of the fetus of rabbit

Most of the anesthetic agents in obstetrics are transmitted to the fetus through the placenta During this period, the effect of the anesthetic agents on the respiratory movements of the fetus, that is, how the fetus react to the anesthetic agents, is the critical problem. Therefore, an experiment was set up whereby direct observation of the ueterus of the pregnant rabbit was possible. Such experiments were reported by Snyder and Rosenfeld, ${ }^{16-20}$ Miyake, ${ }^{21}$ Suzuki,22 and Osanai. 23

a. Method of the experiment: Approximately 40 liters of a bath tub was prepared and Ringer's solution of $39^{\circ} \mathrm{C}$ was poured into the tub. The lower half the body of the rabbit was put into the solution and then the uteri were exposed. 
Then the respiratory movements of the fetus were counted per minute. The observation time was approximately one hour.

1) Open drop method (M.T.F.): The volume of M.T.F. which was administered was $0.1,0.5$ and $1.5 \mathrm{ml}$, respectively.

a) $0.1 \mathrm{ml}-\mathrm{The}$ gestation of the rabbit was 26 days. Body weight of rabbit was $3,350 \mathrm{~g}$. Seven fetuses were observed. Two minutes after the beginning of anesthesia, apnea was noted. Four minutes later, 2 of them started to respirate and 16 minutes later, most of them recovered. Five of the 7 fetuses respirated upon delivery by incision of the uterus. The other two respirated 30 seconds later.

b) $0.5 \mathrm{ml}$-The gestation was 28 days. Body weight of the rabbit was $4,000 \mathrm{~g}$. Four fetuses were observed. Six minutes after the start of anesthesia, apnea were noted and lasted for 14 minutes. Respiration started from 10 to 30 seconds after birth.

c) $1.5 \mathrm{ml}-0.5 \mathrm{ml}$ of M.T.F. was dropped three times intermittently. Twenty seven days gestation of rabbit was used. Body weight of the rabbit was $3,250 \mathrm{~g}$. Five fetuses were observed. There was no change in the respiration by dropping of $0.5 \mathrm{ml}$ of M.T.F. The same dosage of M.T.F. was added twice and the mother rabbit died at 16 minutes after the start of the anethesia. Two minutes after the death of the mother, the respiratory movements of the fetus stopped and all fetuses were dead upon delivery.

2) Mask method with oxygen administration: M.T.F. was administered through Pentec vaporizer with oxygen 5 to 10 liters per minute. The concentration of M.T.F. in the mask was $0.5,1.0$ and $1.5 \%$, respectively.

a) $0.5 \%$-The gestation of the rabbit was 26 days. The body weight was $2,900 \mathrm{~g}$. Six fetuses were observed. No decrease in the number of respirations was observed. The first respiratory movements of the fetus was noted 2 to 118 seconds after the delivery.

b) $1.0 \%$-The gestation of the rabbit was 25 days. The body weight was $2,980 \mathrm{~g}$. Five fetus were observed. Respiration tended to increase after beginning the anethesia, but 5 minutes after the beginning, it tended to decrease. The first respiratory movement upon delivery was noted in one to 20 seconds.

c) $1.5 \%$ - The gestation of the rabbit was 28 days. The body weight was $3,500 \mathrm{~g}$. Three fetuses were observed. Respiration tended to decrease after the beginning of anethesia. Upon delivery, $(8$ minutes after the beginning of anesthesia), one fetus respirated but did not move, the other moved, but did not respirate, and the third did not respirate or moved (expired?).

b. Summary: Oxygen administration to the mother was useful when 
respiration of the fetus was depressed by the anesthetic agent. Anesthesia should be interrupted and oxygen should be administered by inhalation anesthesia. Therefore, in obstetrical anesthesia, inhalation anesthesia should be administered only during labor pain while oxygen should be administered either alone or in conjunction with inhalation anesthesia.

\section{Respiration of tissue (M.T.F.)}

How the fetus reacts to the anethetic agent was tested by respiration of the tissue of rabbit, which was felt to represent the metabolism of a fetus.24

a. Method of experiment: The gestation of the rabbit was 26 days and the body weight was $2,900 \mathrm{~g}$. Six milliliter of M.T.F. were administered to the rabbit through a Pentec vaporizer for 10 minutes. At the same time, $200 \mathrm{ml}$ per minute of oxygen were also administered. Then the rabbit was decapitated and the organs were extracted. The organs were homogenized in $10 \%$ of Krebsringer's solution, and one $\mathrm{ml}$ of the solution was put into a main chamber of Warburg's pressure meter. $\mathrm{CO}_{2}$ was absorbed through a sub-chamber which contained $0.3 \mathrm{ml}$ of $\mathrm{KOH}$. The manometer was checked 4 times in 60 minutes and the record was shown in $\mathrm{QO}_{2}$.

b. Result (Table 6): As the table shows, there was some disturbance in respiration of the organs of the fetus (decrease of $\mathrm{QO}_{2}$ ) by M.T.F., but it was not great and $\mathrm{QO}_{2}$ of the mother's diencephalon rather increased. There was almost no change in the placenta.

Table 6

$Q \mathrm{O}_{2}$ per $0.2 \mathrm{~g}$ of organs $(\mu l)$

\begin{tabular}{|c|c|c|c|c|c|}
\hline Organs & & $10 \mathrm{~min}$ & $20 \mathrm{~min}$ & $40 \mathrm{~min}$ & $60 \mathrm{~min}$ \\
\hline $\begin{array}{l}\text { Diencephalon } \\
\text { of Mother }\end{array}$ & $\begin{array}{l}\text { Anesthesia } \\
\text { Control }\end{array}$ & $\begin{array}{l}37.00 \\
19.35\end{array}$ & $\begin{array}{l}53.65 \\
23.76\end{array}$ & $\begin{array}{l}83.25 \\
48.93\end{array}$ & $\begin{array}{r}112.85 \\
76.45\end{array}$ \\
\hline Heart of Fetus & $\begin{array}{l}\text { Anesthesia } \\
\text { Control }\end{array}$ & $\begin{array}{l}32.00 \\
48.62\end{array}$ & $\begin{array}{l}38.00 \\
52.36\end{array}$ & $\begin{array}{l}40.00 \\
56.10\end{array}$ & $\begin{array}{l}46.00 \\
61.71\end{array}$ \\
\hline $\begin{array}{l}\text { Kidney of } \\
\text { Fetue }\end{array}$ & $\begin{array}{l}\text { Anesthesia } \\
\text { Control }\end{array}$ & $\begin{array}{l}13.44 \\
14.80\end{array}$ & $\begin{array}{l}37.28 \\
59.20\end{array}$ & $\begin{array}{r}89.24 \\
103.60\end{array}$ & $\begin{array}{l}127.24 \\
155.40\end{array}$ \\
\hline Liver of Fetus & $\begin{array}{l}\text { Anesthesia } \\
\text { Control }\end{array}$ & $\begin{array}{l}11.64 \\
10.44\end{array}$ & $\begin{array}{l}11.64 \\
13.92\end{array}$ & $\begin{array}{l}19.40 \\
24.36\end{array}$ & $\begin{array}{l}31.04 \\
34.80\end{array}$ \\
\hline Brain of Fetus & $\begin{array}{l}\text { Anesthesia } \\
\text { Control }\end{array}$ & $\begin{array}{l}11.28 \\
13.60\end{array}$ & $\begin{array}{l}18.80 \\
17.00\end{array}$ & $\begin{array}{l}30.08 \\
37.40\end{array}$ & $\begin{array}{l}37.60 \\
47.60\end{array}$ \\
\hline Placenta & $\begin{array}{l}\text { Anesthesia } \\
\text { Control }\end{array}$ & $\begin{array}{l}7.84 \\
8.20\end{array}$ & $\begin{array}{l}11.76 \\
10.36\end{array}$ & $\begin{array}{l}15.68 \\
14.97\end{array}$ & $\begin{array}{l}17.34 \\
16.56\end{array}$ \\
\hline
\end{tabular}


B. Clinical Experiments

1. Classification of asphyxia of newborn infants

There are some classifications of asphyxia ${ }^{25-28}$ to show the degree of depression of the newborn infants. To find out which classification is the most suitable, 641 newborn infants were classified in each classification.

a. Cazean's classification: As the table 7 shows, when Cazean's classification

Table $\gamma$

Cazean's Classification

(Delivery under anesthesia)

\begin{tabular}{c|c|c|c|c|c|c|c}
\hline \hline \multirow{2}{*}{ Vaporizer } & $\begin{array}{c}\text { No. of } \\
\text { cases }\end{array}$ & \multicolumn{2}{|c|}{ None } & \multicolumn{2}{|c|}{ 1st degree } & \multicolumn{2}{|c}{ 2nd degree } \\
\cline { 2 - 8 } & Case & $\%$ & Case & $\%$ & Case & $\%$ \\
\hline $\begin{array}{c}\text { Nitrous Oxide } \\
\text { (Walton-V) }\end{array}$ & 148 & 141 & 95.27 & 5 & 3.38 & 2 & 1.35 \\
$\begin{array}{c}\text { Trichlorethylene } \\
\text { (Goldman) }\end{array}$ & 210 & 199 & 94.76 & 8 & 3.81 & 3 & 1.43 \\
$\begin{array}{c}\text { Halothane } \\
\text { (Fluotec) }\end{array}$ & 283 & 267 & 95.06 & 10 & 3.53 & 4 & 1.41 \\
\hline Total & 641 & 609 & 95.02 & 23 & 3.58 & 9 & 1.40 \\
\hline
\end{tabular}

was used, the frequency of the asphyxia of the infants is $4.98 \%$.

b. Flagg's classification: As the table 8 shows, when Flagg's classification was used, asphyxia could be classified in detail; that is, first degree $4.05 \%$, sec-

Table 8

Flagg's Classification

(Delivery under anesthesia)

\begin{tabular}{c|c|c|c|c|c|c|c|c|c}
\hline \multirow{2}{*}{ Vaporizer } & \multirow{2}{*}{$\begin{array}{c}\text { No. of } \\
\text { cases }\end{array}$} & \multicolumn{2}{|c|}{ None } & \multicolumn{2}{|c|}{ 1st degree } & \multicolumn{2}{|c|}{ 2nd degree } & \multicolumn{2}{c|}{ 3rd degree } \\
\cline { 3 - 10 } & Case & $\%$ & Case & $\%$ & Case & $\%$ & Case & $\%$ \\
\hline $\begin{array}{c}\text { Nitrous Oxide } \\
\text { (Walton-V) }\end{array}$ & 148 & 139 & 93.91 & 6 & 4.05 & 2 & 1.35 & 1 & 0.69 \\
$\begin{array}{c}\text { Trichlorethy- } \\
\text { lene (Goldman) }\end{array}$ & 210 & 196 & 93.34 & 10 & 4.76 & 2 & 0.95 & 2 & 0.95 \\
$\begin{array}{c}\text { Halothane } \\
\text { (Fluotec) }\end{array}$ & 283 & 267 & 94.36 & 10 & 3.53 & 4 & 1.41 & 2 & 0.70 \\
\hline Total & 641 & 609 & 93.93 & 26 & 4.05 & 8 & 1.24 & 5 & 0.78 \\
\hline
\end{tabular}


ond degree $1.24 \%$ and third degree $0.78 \%$.

c. Lund's classification: As the table 9 shows, when Lund's classification

\section{Table 9}

Lund's Classification

(Delivery under anesthesia)

\begin{tabular}{c|c|c|c|c|c|c|c|c|c}
\hline \hline \multirow{2}{*}{ Vaporizer } & \multirow{2}{*}{$\begin{array}{c}\text { No. of } \\
\text { case }\end{array}$} & \multicolumn{2}{|c|}{ None } & \multicolumn{2}{|c|}{ Slight } & \multicolumn{2}{c|}{ Moderate } & \multicolumn{2}{c|}{ Severe } \\
\cline { 3 - 10 } & Case & $\%$ & Case & $\%$ & Case & $\%$ & Case & $\%$ \\
\hline $\begin{array}{c}\text { Nitrous Oxide } \\
\text { (Walton-V) }\end{array}$ & 148 & 138 & 93.24 & 7 & 4.72 & 2 & 1.35 & 1 & 0.69 \\
$\begin{array}{c}\text { Trichlorethy- } \\
\text { lene (Goldman) }\end{array}$ & 210 & 196 & 93.34 & 10 & 4.76 & 2 & 0.95 & 2 & 0.95 \\
$\begin{array}{c}\text { Halothane } \\
\text { (Fluotec) }\end{array}$ & 283 & 265 & 93.64 & 12 & 4.24 & 3 & 1.06 & 3 & 1.06 \\
\hline Total & 641 & 599 & 93.46 & 29 & 4.52 & 7 & 1.09 & 6 & 0.93 \\
\hline
\end{tabular}

was used, the asphyxia could be classified in detail ; that is, slight degree $4.52 \%$, moderate degree $1.09 \%$ and severe degree $0.93 \%$.

d. Silverman's classification: As the table 10 shows, when Silverman's

Table 10

Silverman's Classification

(Delivery under anesthesia)

\begin{tabular}{c|c|c|c|c|c|c|c|c|c}
\hline \hline \multirow{2}{*}{ Vaporizer } & $\begin{array}{c}\text { No. of } \\
\text { cases }\end{array}$ & \multicolumn{2}{|c|}{ 0 Point } & \multicolumn{2}{|c|}{1 Point } & \multicolumn{2}{|c|}{ 2 Points } & \multicolumn{2}{c|}{ Above 3 Points } \\
\cline { 2 - 11 } & Case & $\%$ & Case & $\%$ & Case & $\%$ & Case & $\%$ \\
\hline $\begin{array}{c}\text { Nitrous Oxide } \\
\text { (Walton-V) }\end{array}$ & 148 & 128 & 86.50 & 12 & 8.10 & 6 & 4.05 & 2 & 1.35 \\
$\begin{array}{c}\text { Trichlorethy- } \\
\text { lene (Goldman) }\end{array}$ & 210 & 190 & 90.49 & 14 & 6.66 & 4 & 1.90 & 2 & 0.95 \\
$\begin{array}{c}\text { Halothane } \\
\text { (Fluotec) }\end{array}$ & 283 & 269 & 91.53 & 17 & 6.00 & 4 & 1.41 & 3 & 1.06 \\
\hline Total & 641 & 587 & 90.03 & 43 & 6.70 & 14 & 2.18 & 7 & 1.09 \\
\hline
\end{tabular}

classification is used, it was possible to classify asphyxia in detail; that is, one point $6.70 \%$, two points $2.18 \%$ and three points or above as $1.09 \%$.

e. Summary: In deliveries under anesthesia, asphyxia of the baby is an important problem. According to these classifications, asphyxia developed as 
follows: With trichlorethylene $(5.24 \%$ by Cazean's classification and $6.66 \%$ by Flagg's classification); with nitrous oxide (6.7\% by Lund's classification and $13.50 \%$ by Silverman's classification). In other words, the percentage of asphyxia varied when different classifications were used. Therefore, "sleepy baby" as defined by the ordinary classification of asphyxia should be taken into consideration.

2. Primary reflexes of the newborn infants

Since the nervous system in the newborn infant is not fully developed, cortical inhibition is not yet developed. There is thus a great deal of reflex behavior expressed in the motor reactions of the infants. Development appears to be related to myelination, cephalad to caudad. The functions of the infant's central nervous system in the early stage were shown only in their reflexes so that the sucking, light, sound, Perez's and Moro's reflexes ${ }^{29-32}$ were pursued daily. These results were compared with those of 2,592 cases of non-anesthetized deliveries in our affiliated hospital, (Keio University Hospital in Tokyo). In our hospital the light reflex was $68 \%$ positive as contrasted to $94 \%$ at Keio), the sound reflex was $0 \%$ positive (Keio $33 \%$ ), Moro's reflex was $86 \%$ positive (Keio 92\%), and Perez's reflex was $51 \%$ positive (Keio $79 \%$ ) upon delivery. Therefore, it appeared that the percentage was lower in the anesthetized deliveries as compared to those in the non-anesthetized deliveries. However, these became equal 2 days after delivery.

a. Nitrous oxide: As shown on the table 11, when nitrous oxide was used, the sucking, light, Perez's Moro's reflexes became positive in the first day of delivery. Only the sound reflex required 5 days after delivery until it became positive.

b. Trichlorethylene: As the table 12 shows, when trichlorethylene was used, the sucking, light and Moro's refiexes and the bending of upper and lower extremities and crying of Perez's reflex became positive in the first day after delivery but the raising of the buttocks, bending of spines and the raising of head required 2 days until they became positive. The sound reflex needed 5 days until it became positive.

c. Halothane: As the table 13 showed, when Halothane was used, the sucking and Moro's reflex became positive in the first day after delivery, but the light and Perez's reflexes were noted 2 days later. The sound reflex needed 5 days until it became positive.

d. Summary: When nitrous oxide was used, all reflexes became positive in the first day after delivery. On the contrary, when trichlorethylene was used, 


\begin{tabular}{|c|c|c|c|c|c|c|c|}
\hline \multirow{2}{*}{$\begin{array}{l}\text { 要 } \\
\text { 范 }\end{array}$} & $\therefore$ & $\stackrel{8}{\stackrel{8}{\circ}}$ & & \multirow{2}{*}{\multicolumn{2}{|c|}{ 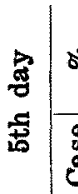 }} & \multicolumn{2}{|r|}{$\stackrel{8}{\circ}$} \\
\hline & 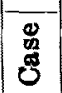 & N & & & $\overline{0}$ & & N \\
\hline \multirow{2}{*}{$\begin{array}{l}\frac{8}{8} \\
\frac{5}{\xi}\end{array}$} & x゚ & 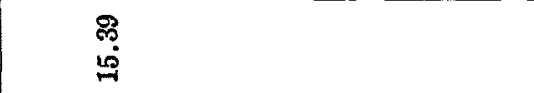 & & \multirow{2}{*}{\multicolumn{2}{|c|}{ 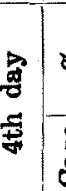 }} & \multicolumn{2}{|r|}{$\stackrel{8}{\circ}$} \\
\hline & 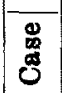 & $*$ & & & 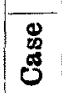 & & N \\
\hline \multirow[t]{2}{*}{$g$} & 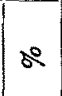 & $\stackrel{8}{\circ}$ & & \multirow{2}{*}{ 密 } & \multirow{2}{*}{$\begin{array}{l}20 \\
0 \\
0 \\
0\end{array}$} & \multicolumn{2}{|r|}{ 点 } \\
\hline & 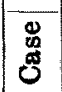 & w & & & & & $\infty$ \\
\hline \multirow{2}{*}{ 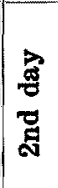 } & $\therefore$ & 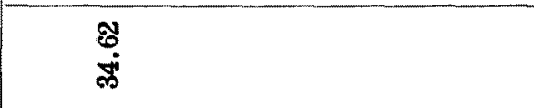 & & \multirow{2}{*}{ 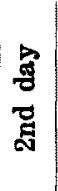 } & $s^{\circ}$ & & $\underset{\infty}{5}$ \\
\hline & 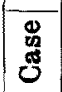 & $\infty$ & & & 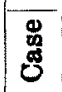 & & $\rightarrow \quad r-1$ \\
\hline \multirow{2}{*}{ 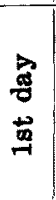 } & \multicolumn{2}{|r|}{ \& } & \multirow{4}{*}{ 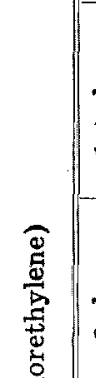 } & \multirow{2}{*}{ 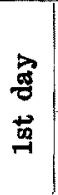 } & \multicolumn{3}{|c|}{ 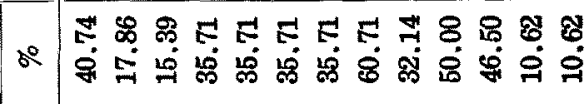 } \\
\hline & \begin{tabular}{|l|l}
0 \\
0 \\
0 \\
0
\end{tabular} & 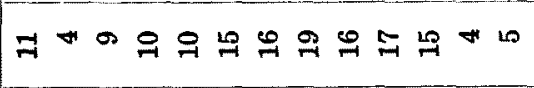 & & & 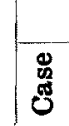 & \multicolumn{2}{|c|}{ 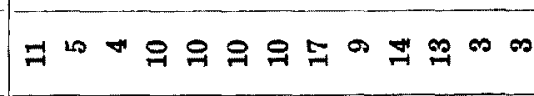 } \\
\hline & 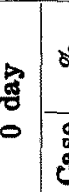 & 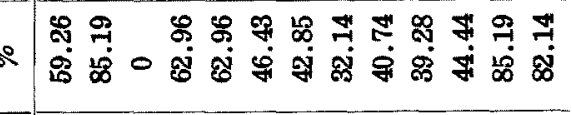 & & \multirow{2}{*}{ - } & \multirow{2}{*}{$\mid \begin{array}{l}\infty \\
0 \\
0 \\
0\end{array}$} & \multicolumn{2}{|c|}{ 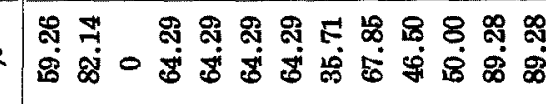 } \\
\hline & \multicolumn{2}{|r|}{ 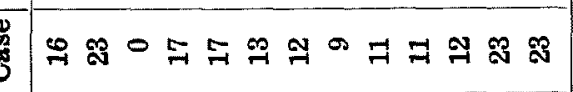 } & & & & \multicolumn{2}{|c|}{ 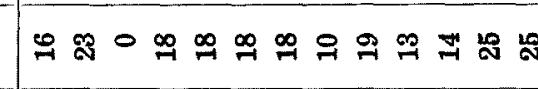 } \\
\hline & 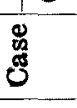 & ธ & & & 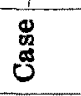 & $\llcorner\stackrel{\infty}{*}$ & 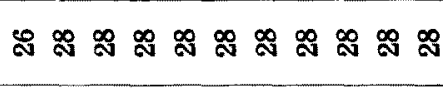 \\
\hline & & 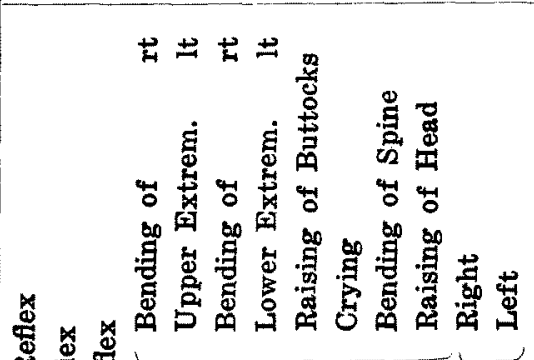 & 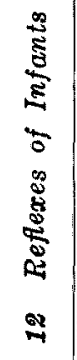 & & & 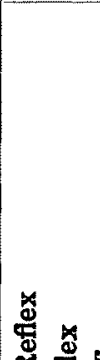 & 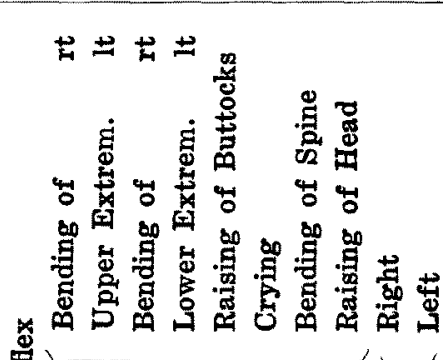 \\
\hline & & 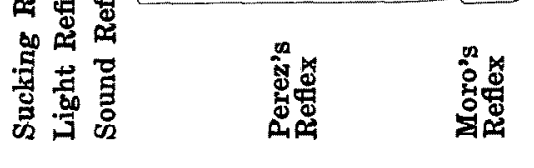 & 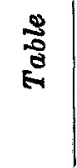 & & & 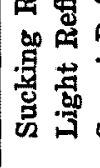 & 要 \\
\hline
\end{tabular}



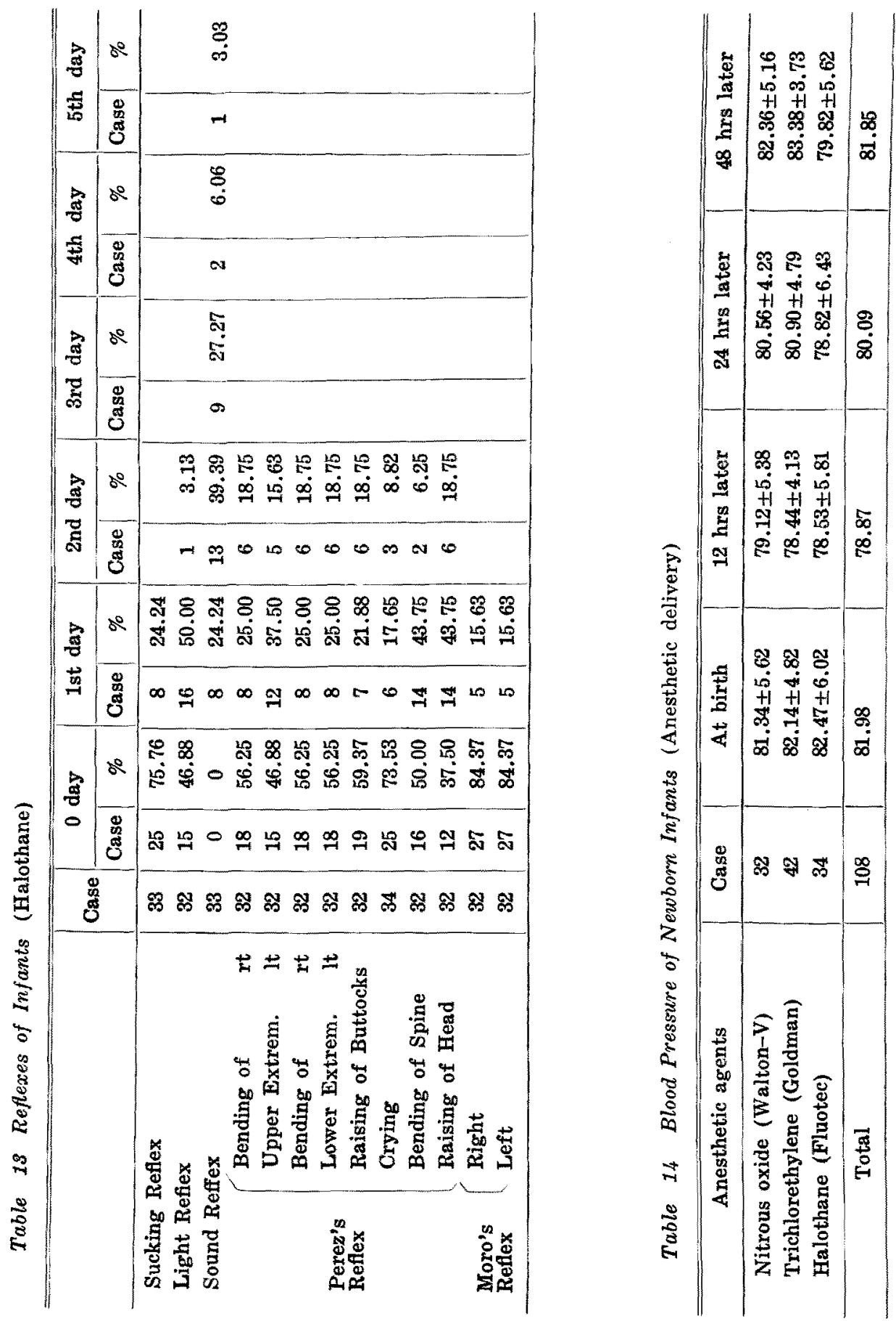
the raising of the buttocks, bending of spine, raising of head of Perez's reflex needed 2 days until they became positive. When Halothane was used, the light and Perez's reflexes needed 2 days until they became positive. This fact coincides with the fact that Halothane has the deepest effect of anesthesia.

3. Blood pressure of the newborn infants

According to Ashworth et al.,33,34 in normal babies the systolic blood pressure fell significantly during the first 24 hours of life. In our study blood pressure of the newborn infants was checked at birth, 12, 24 and 48 hours after birth, respectively; The sphygmomanometer which was deviced by $\mathrm{Baba}^{35}$ was used for the investigation. The result was shown on table 14 .

a. Nitrous oxide: At birth, the mean blood pressure was $8.34 \pm 5.62 \mathrm{mmHg}$. Twelve hours later, it dropped down to $79.12 \pm 5.38 \mathrm{mmHg}$ and recovered to $82.36 \pm 5.16 \mathrm{mmHg}$ at 48 hours later.

b. Trichlorethylene: At birth, the mean blood pressure was $82.14 \pm 4.82$ $\mathrm{mmHg}$. Twelve hours later, it dropped down to $78.44 \pm 4.13 \mathrm{mmHg}$ and recovered $82.36516 \mathrm{mmHg}$ at 48 hours later.

c. Halothane: At birth, the mean blood pressure was $82.47 \pm 6.02 \mathrm{mmHg}$. Twelve hours later, it dropped down to $78.53 \pm 5.81 \mathrm{mmHg}$ and it did not recover at 48 hours later. $(79.82 \pm 5.62 \mathrm{mmHg})$.

d. Summary: The blood pressure of newborn infants, in general, was the highest at birth $(81.98 \mathrm{mmHg})$ and then dropped. It recovered 48 hours later after birth in nitrous oxide and trichlorethylene, but it did not recover in Halothane. When these results are compared with those by Kawamoto, ${ }^{36}$ the former was $8 \mathrm{mmHg}$ lower than the latter at birth. The former was still lower by $5 \mathrm{mmHg}$ than the latter at 24 to 48 hours after birth.

\section{Icterometer on newborn infants}

About 50 per cent of all newborn infants became visibly jaundiced. This physiologic icterus usually appears on the second or third day of life, regresses by the seventh, and disappeares by the fourteenth. ${ }^{35}$ Recently, the icterometer had been used to check the jaundice of the newborn infants. ${ }^{38}$ To check the jaundice of the newborn infants who were delivered under anesthesia, the icterometer of Gosset was used. The jaundice was checked at 10 a.m. on the first, second, third, fourth and fifth day of birth. Use of the phenothiazine at the same time in the first stage of delivery was also discussed. The result was as table 15.

a. Ntirous oxide: When nitrous oxide was used for anesthesia, the ictero- 
Table 15

Icterometer of Newborn Infants

(Anesthetic delivery)

\begin{tabular}{|c|c|c|c|c|c|c|c|c|c|}
\hline $\begin{array}{l}\text { Mode of } \\
\text { delivery }\end{array}$ & $\begin{array}{c}\text { Anesthetic } \\
\text { agents }\end{array}$ & $\begin{array}{l}\text { Phenothi- } \\
\text { azine }\end{array}$ & Case & 0 day & 1st day & $\begin{array}{l}\text { 2nd } \\
\text { day }\end{array}$ & $\begin{array}{l}\text { 3rd } \\
\text { day }\end{array}$ & $\begin{array}{l}\text { 4th } \\
\text { day }\end{array}$ & $\begin{array}{l}\text { 5th } \\
\text { day }\end{array}$ \\
\hline \multirow{3}{*}{$\begin{array}{l}\text { Vaginal } \\
\text { delivery }\end{array}$} & $\begin{array}{l}\text { Nitrous } \\
\text { oxide } \\
\text { (Walton-V) }\end{array}$ & $\begin{array}{l}\text { Used } \\
\text { Not used }\end{array}$ & $\begin{array}{r}8 \\
59\end{array}$ & $\begin{array}{l}0.11 \\
0.66\end{array}$ & $\begin{array}{l}1.12 \\
1.23\end{array}$ & $\begin{array}{l}2.54 \\
2.10\end{array}$ & $\begin{array}{l}2.27 \\
2.36\end{array}$ & $\begin{array}{l}1.68 \\
2.03\end{array}$ & $\begin{array}{l}1.50 \\
1.45\end{array}$ \\
\hline & $\begin{array}{l}\text { Trichlore- } \\
\text { thylene } \\
\text { (Goldman) }\end{array}$ & $\begin{array}{l}\text { Used } \\
\text { Not used }\end{array}$ & $\begin{array}{r}6 \\
42\end{array}$ & $\begin{array}{l}0.00 \\
0.00\end{array}$ & $\begin{array}{l}2.10 \\
1.80\end{array}$ & $\begin{array}{l}2.71 \\
2.54\end{array}$ & $\begin{array}{l}2.09 \\
2.30\end{array}$ & $\begin{array}{l}2.38 \\
2.21\end{array}$ & $\begin{array}{l}1.69 \\
1.60\end{array}$ \\
\hline & $\begin{array}{l}\text { Halothane } \\
\text { (Fluotec) }\end{array}$ & $\begin{array}{l}\text { Used } \\
\text { Not used }\end{array}$ & $\begin{array}{r}6 \\
40\end{array}$ & $\begin{array}{l}0.08 \\
0.09\end{array}$ & $\begin{array}{l}1.51 \\
1.61\end{array}$ & $\begin{array}{l}2.16 \\
2.30\end{array}$ & $\begin{array}{l}2.50 \\
2.46\end{array}$ & $\begin{array}{l}2.16 \\
2.27\end{array}$ & $\begin{array}{l}1.72 \\
1.88\end{array}$ \\
\hline C-section & $\begin{array}{l}\text { Halothane } \\
\quad+ \\
\text { Nitrous } \\
\text { oxide } \\
\text { (Boyle-K) }\end{array}$ & $\begin{array}{l}\text { Used } \\
\text { Not used }\end{array}$ & $\begin{array}{r}0 \\
19\end{array}$ & 0.06 & $\overline{1.48}$ & $\overline{2.33}$ & 2.40 & 2.25 & $\overline{1.50}$ \\
\hline \multicolumn{3}{|c|}{ Total } & 180 & 0.12 & 1.55 & 2.38 & 2.34 & 2.14 & 1.62 \\
\hline
\end{tabular}

meter showed already $\mathbf{0 . 6 6}$ on the first day of birth. It gradually increased and showed the peak (2.36) on the third day of birth and then gradually decreased.

b. Trichlorethylene: When trichlorethylene was used for anesthesia, the iceterometer showed 1.80 on the first day of birth. It showed the highest value (2.54) on the second day of birth and then the index gradually decreased.

c. Halothane: When Halothane was used for anesthesia, the icterometer already showed 0.09 on the day of birth. The index then gradually increased and showed the highest value (2.46) on the third day of birth and then decreased.

d. Cesarean section: When Halothane was used for cesarean section, the icterometer showed 0.06 on the day of birth. It gradually increased and showed the highest value (2.40) on the third day of birth and then gradually decreased.

e. Phenothiazine: Some authors ${ }^{39,40}$ stated that when phenothiazine was used for anesthesia of delivery, the jaundice of the babies increased. However, no such tendency was noted in our experiment.

f. Summary: There was no difference in the degree of jaundice of babies when different kind of anesthetic agents were used for delivery. There was also no difference in cesarean sections and no difference was noted when phenothiazine was used for anesthetic deliveries.

5. Body weight of newborn infants

In the first three or four days of life the infant loses weight. He may lose 
up to 10 per cent of his birth weight without causing concern; small infants lose proportionately less than large ones. ${ }^{41}$ Usually, by the fifth day, the infant begins to gain; many infants regain their birth weight by the tenth day, and most by the fourteenth. ${ }^{42,43}$ There are many factors which relates to the decrease of body weight of newborn infants. In our research, the body weight

Table 16

Ratio of Decrease of Body Weight of Infants

(Anesthetic delivery)

\begin{tabular}{|c|c|c|c|}
\hline Mode of delivery & Anesthetic agents & Case & $\begin{array}{l}\text { Ratio of decrease } \\
\text { of body weight }(\%)\end{array}$ \\
\hline Vaginal delivery & $\begin{array}{l}\text { Nitrous oxide (Walton-V) } \\
\text { Trichlorethylene (Goldman) } \\
\text { Halothane (Fluotec) }\end{array}$ & $\begin{array}{l}67 \\
48 \\
46\end{array}$ & $\left.\begin{array}{l}3.16 \\
3.10 \\
3.20\end{array}\right\} 3.30$ \\
\hline \multirow[t]{2}{*}{ C-section } & $\begin{array}{l}\text { Halothane }+ \text { Nitrous oxide } \\
\qquad(\text { Boyle-K) }\end{array}$ & 19 & 3.21 \\
\hline & Total & 180 & 3.28 \\
\hline
\end{tabular}

of babies who were delivered under anesthesia was checked daily until the fifth day of birth. The results was as table 16 .

a. Vaginal delivery: When nitrous oxide was used for the anesthesia, the ratio of decrease of body weight of babies was $3.61 \%$; when trichlorethylene was used, it was $3.10 \%$; and when Halothane was used, it was $3.20 \%$. There was no significant correlation among them.

b. Cesarean section: When Halothane was used for cesarean section, the ratio of decrease of body weight of babies was $3.21 \%$. There was no correlation with vaginal deliveries.

c. Summary: The anesthetic vaginal delivery and cesarean section have no influence on the body weight of babies.

\section{CONCLUSION}

Introvenous anesthetic agents was more easily transmitted to the fetus through the placenta than the inhalation anesthetic agents. Therefore, the inhalation anesthesia was safer for the fetus than intravenous anesthesia in this respect. There was no correlation between the blood concentration of the anesthetic agents and the depression of infants. 
1. Concentration in the blood of mothers and infants: Concentration of an intravenous anesthetic agent and the inhalation anesthetic agents were analyzed by gas chromatography, a) Transmission of intravenous anesthesia by thiopental was studied in 13 cases. During the time interval from induction of anesthesia until birth (which was as long as $21^{\prime} 40^{\prime \prime}$ in one case), there was no definite relationship in the concentration of anesthetic agents transmitted through the placenta with lapse of time. The time when the anesthetic agent appeared in blood and reached its highest concentration took longer than the other reports. b) Transmission of inhalation anesthesia by M.T.F. was studied in 20 vaginal deliveries. The mean inhalation time was for 24 minutes. The concentration of M.T.F. in the venous blood of mothers was $5.3 \% \mathrm{mg} / \mathrm{dl}$ and $24.9 \%$ of the latter was transmitted to the fetus. c) Transmission of inhalation anesthesia by Halothane was studied in 42 vaginal deliveries and 9 cesarean sections. The mean inhalation time for vaginal delivery was 32 minutes. The concentration of Halothane in the arterial blood of mothers upon vaginal delivery was $4.5 \mathrm{mg} / \mathrm{dl}$ and $55.2 \%$ of the latter was transmitted to the fetus. The concentration of arterial blood of mother upon cesarean section was $9.7 \mathrm{mg} / \mathrm{dl}$ and $65.5 \%$ of this figure was transmitted to the fetus. The concentration of Halothane in the intravillous space was $7.3 \mathrm{mg} / \mathrm{dl}$. The mean inhalation time with cesarean section was 24 minutes. d) Transmission of inhalation anesthesia with trichlorethylene was studied in 34 vaginal deliveries. The concentration of trichlorethylene in the arterial blood of mothers was $2.8 \mathrm{mg} / \mathrm{dl}$ and $65.4 \%$ of the latter was transmitted to the fetus. The mean inhalation time was 35 minutes. e) Transmission of inhalation anesthesia by nitrous oxide was studied in 20 vaginal deliveries and 6 cesarean sections. The concentration of nitrous oxide in the arterial blood of mothers upon vaginal delivery was $23.8 \mathrm{mg} / \mathrm{dl}$ and $46.3 \%$ of this concentration was transmitted to the fetus. The mean inhalation time was 24 minutes. The concentration of nitrous oxide in arterial blood of mothers upon cesarean section was $26.3 \mathrm{mg} / \mathrm{dl}$ and $70.5 \%$ of this figure was transmitted to the fetus. At that time, the mean inhalation time was 24 minutes and the concentration of blood in the intravillous space was $24.5 \mathrm{mg} / \mathrm{dl}$.

2. Concentration of anesthetic agent in the organs of rabbits and human being: a) Trichlorethylene was given to three pregnant rabbits for 12'20" (mean) ; at this time, the concentration of arterial blood of mother was $2.6 \mathrm{mg} / \mathrm{dl}$. Only a trace of trichlorethylene was noted in the brain, liver and kidneys of the fetus and no trichlorethylene was noted in the heart of fetus. b) Trichlorethylene $(0.70 \%)$ was inhaled by a mother of 22 weeks gestation. At that time, 
the concentration of the anesthetic agent in the arterial blood of mother was $3.0 \mathrm{mg} / \mathrm{dl}$ and the concentration in the heart of fetus was $0.9 \mathrm{mg} / 100 \mathrm{~g}$. No trichlorethylene was noted in the placenta and the brain, liver and kidneys of the fetus.

3. Respiration of tissue of rabbits: Respiration of tissue of pregnant rabbits upon M.T.F. administration was studied. There was slight decrease of $\mathrm{QO}_{2}$ of the organs of fetus; however, an increase of $\mathrm{QO}_{2}$ was noted in the diencephalon of the mother. No change was noted in the placenta.

4. Primary reflexes of newborn infants, blood pressure of newborn infants, icterometer on newborn infants and body weight of newborn infants under anesthetic delivery were studied. A relatively significant difference with each anesthetic agent was noted only in the primary reflexes, that is, all reflexes of newborn infants who were delivered under nitrous oxide anethesia became positive on the first day of birth. On the contrary, it required 2 days after birth for the light and Perez's reflexes of newborn infants delivered under Halothane anesthesia to become positive.

\section{ACKNOWLEDGEMENT}

I wish to express my appreciation to Professor Yukio Notake, Chairman of the OB-GYN Dept. of Keio University for his valuable suggestions and review of this paper. I also wish to express my thanks to Dr. K. Osanai, the Chairman of OB-GYN Dept. of Keiyu Hospital for his kind guidance. The assistance of my colleagues at Keiyu Hospital is gratefully acknowledged.

\section{REFERENCES}

1. Hellman, L. M., Shettles, L. B., Manshan, C. P., and Eastman, N. J.: Sodium pentothal anesthesia in obstetrics. Am. J. Obst. \& Gynec., 81: 948, 1961.

2. Parker, K.D. and Kirk, P.L.: Separation and Identification of Barbiturates by Gas Chromatography. Analyt. Chemist., 33: 10, 1961.

3. McAllister, H. A. and Flowers, C. E.: Evaluation of pentothal sodium for delivery. South. Med. J., 49: 1028, 1956.

4. Crowford, J. S.: Some aspects of obstetric anesthesia, use of thiopentone sodium. Brit. J. Anesth., 28: 146, 1955.

5. McKechnie R. B. and Converse, J. G.: Placental transmission of thiopental. Am. J. Obst. \& Gynec., 70: 639, 1955.

6. Fealy, J.: Placental transmission of pentobarbital sodium. Obst. \& Gynec., 11: $342,1958$.

7. Flowers, C. E. et al.: The placental transmission of barbiturate and thiobarbiturates and their pharmacological action on the mother and the infant. Am. 
J. Obst. \& Gynec., 78: 730, 1959.

8. Sheridan, C. A. and Robson, J. F.: Fluothane in obstetrical anesthesia. Canad. Anesth. Soc. J., 6: 365, 1959.

9. Fujio, T., Matsuoka, M., and Ogawa, M.: Painless delivery by trichlorethylene and the concentration in blood. Obst. \& Gynec. 22: 337, 1955. (in Japanese)

10. Brain, F. H. and Hellwell, P. J.: Estimation of trichlorethylene in blood. Biochem. J., 45: 75, 1949.

11. Smith, C. A.: The effect of obstetrical anesthesia upon the oxygenation of maternal and fetal blood with particular reference to cyclopropane. Surg. Gynec. \& Obst., 69: 584, 1939.

12. Cohen, E. N., Paulson, W. J., Wall, J., and Elert, B.: Thiopental, curare and nitrous oxide anesthesia for cesarean section with study on placental transmission. Surg. Gynec. \& Obst., 97: 456, 1953.

13. Person, B. H.: Studies on the accumulation of certain barbiturates in the brain of the human foetus. Acta Obst. \& Gynec. Scandinav., 39: 88, 1960.

14. McKechnie, F. B. and Conners, S. G.: Placental transmission of thiopental. Am. J. Obst. \& Gynec., 70: 639, 1955.

15. Matsumae, Y.: Metabolism of barbiturates, oxygen and sleeping drugs. Progress of medicine, 30:479, 1957. (in Japanese)

16. Rosenfeld, M. and Snyd, F. F.: Foetal respiration in the rabbit. Proc. Soc. Exper. Biol. Med., 33: 576, 1936.

17. Snyder, F. F. and Rosenfeld, M.: Regulation of fetal respiration. Am. J. Physiol., 116: $147,1937$.

18. Snyder, F. F. and Rosenfeld, M.: Direct observation of intrauterine respiratory movements of the fetus and the role of carbon dioxide and oxygen in their regulation. Am. J. Physiol., 11: 153, 1937.

19. Snyder, F. F. and Rosenfeld, M.: Intra-uterine respiratory movements of the human fetus. J.A.M.A., 108: 1946, 1937.

20. Rosenfeld, M. and Snyder, F.: The factor of anesthesia in the pathogenesis of asphyxia neonatorum. Am. J. Obst. \& Bynec., 38: 429, 1939.

21. Miyake, H.: Influence of Evipan sodium on fetus. Jap. J. Obst. \& Gynec., 36: 323,1941 . (in Japanese)

22. Suzuki, T., Iida, N., and Nakao, S.: Influence of Eunal on fetus of rabbit. Obst. \& Gynec., 26: 909, 1959. (in Japanese)

23. Kuniomi, O.: Text of the 15th Jap. Med. Assoc. Gen. Assem. 1959. (in Japanese)

24. Nakajima, S.: Influence of steroid on the tissue respiration. Anesthesia, 6: 101, 1957. (in Japanese)

25. Beck, L.: Uber die Asphyxie der Neugeborenen und deren Behandlung, Geburtsh. u. Frauenh, 15: 12, 1955.

26. Apgar, V.: A proporal for a new method of evaluation of the newborn infant. Curr. Resear. in Anesth. \& Analg., 32: 260, 1953.

27. Hüter, K. A.: Uber Beziehungen zwischen intra-und postpartaler Hypoxie sowie zerebralen spätschshäden beim Kind. Geburtsh. u. Franenh., 22: 9, 1962.

28. Silverman, W. A. and Anderson, D. H.: A controlled clinical trial of effects of water mist on obstructive respiratory signs. Pediatrics., 17: 1, 1956.

29. Bobath, K. and Bobath, B.: Diagnosis of cerebral palsy in infancy. Arch. Dis. Child., 31: 408, 1956.

30. Dietrich, H. F.: A longitudinal study of the Babinski and plantar grasp reflexes in infancy. Am. J. Dis. Child, 94: 265, 1957.

31. Gentry, E. F. and Aldrich, C. A.: Rooting reflex in the newborn infant. Am. J. 
Dis. Child, $75: 528,1948$.

32. Moro, E.: Das Erste Trimenon, München. med. Wchnschr., 65: 1147, 1918.

33. Ashworth, A. M. et al.: Changes in the systolic blood pressure of normal babies during the first twenty-four hours of life, Lancet, 7077: 801, 1959.

34. Dawes, G. S.: Changes in the circulation at birth. Brit. Med. Bull., 17: 148, 1961.

35. Baba, K. et al.: Device of sphygmomanometer for newborn infants and blood pressure of newborn infant. Practice of Pediatrics, 24:5, 1961. (in Japanese)

36. Kawamoto, H.: Blood pressure of newborn infants. Obst. \& Gynec., 39: 3, 1964. (in Japanese)

37. Nelson, W. E.: Textbook of Pediatrics. London, W. B. Saunders, 1959 p. 289.

38. Billing, B. H. and Lathe, G. H.: Bilirubin metabolism in jaundice. Am. J. Med., 24: 111, 1958.

39. Zuelzer, W. W. and Brown, A. K.: Neonatal jaundice. Am. J. Dis. Child., 101: 87, 1961.

40. Behn, W. et al.: Utber den diaplacentaren übergang von phenothiazin derivaten. Klin. Wschr., 34: 872, 1956.

41. Potts, C. R. et al.: Maternal and fetal effects of obstetric analgesia. Am. J. Obst. \& Gynec., 81: 1253, 1961 .

42. Hansen, J. D. L. and Smith, C. A.: Effect of withholding fluid in the immediate postnatal period. Pediatrics, 12: 99, 1953.

43. Hughes, E. A.: Some aspects of starvation in the newborn baby. Arch. Dis. Childhood, 39: 598, 1964. 